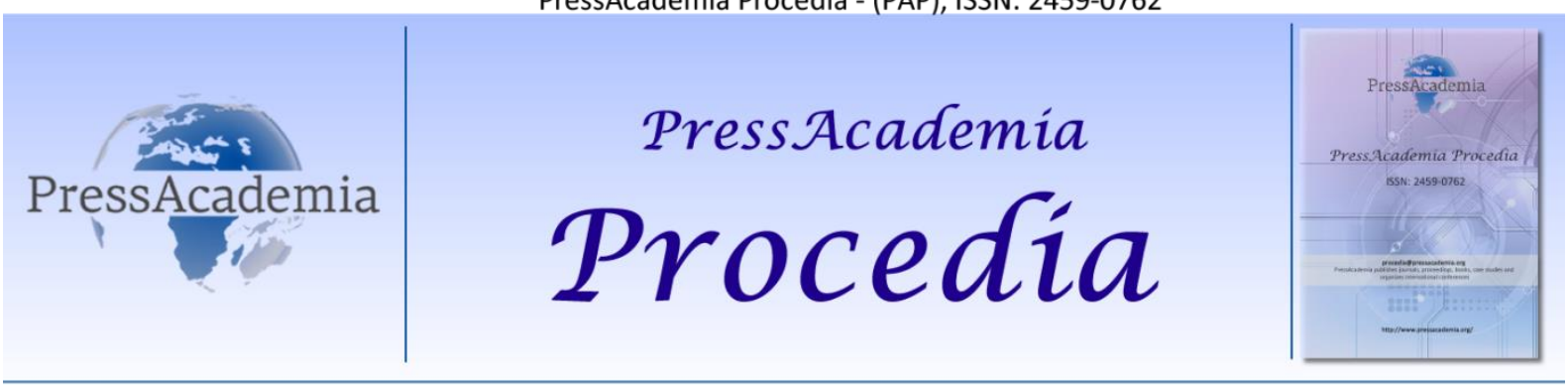

2nd World Conference on Technology, Innovation and Entrepreneurship

May 12-14, 2017, Istanbul, Turkey. Edited by Sefer Şener

\title{
ETHICAL ASPECTS OF ENTREPRENEURSHIP IN NURSING
}

\section{DOI: 10.17261/Pressacademia.2017.519 \\ PAP-WCTIE-V.4-2017(11)-p.70-73}

\author{
Nurten Kaya ${ }^{1}$, Nuray Turan ${ }^{2}$, Gulsun Ozdemir Aydin ${ }^{3}$ \\ ${ }^{1}$ Istanbul University, Health Sciences Faculty, Department of Midwifery. nurka@istanbul.edu.tr \\ ${ }^{2}$ Istanbul University, Florence Nightingale Nursing Faculty, Department of Fundamentals of Nursing, nkaraman@istanbul.edu.tr \\ ${ }^{3}$ Istanbul University, Florence Nightingale Nursing Faculty, Department of Fundamentals of Nursing. gulsunoz@istanbul.edu.tr
}

\begin{abstract}
Ethics is one of the characteristics of contemporary civilization. Health care system faces uniquely complex ethical problems. Many points of serious concern need to be raised under the concept of ethics. For nurse entrepreneurs to be professionally credible they have to be competent and accountable. While fundamental responsibility lies with the individual nurse entrepreneur, the professions have to evidently improve these essential attributes as well. The code of nursing ethics would constitute supplementation of legal provisions and professional regulations. There is growing recognition of the important contributions made by nurse entrepreneurs within health care systems and an acknowledgement that nurse entrepreneurship promises future advancement in health care. As a consequence, ethics will contribute to harmonious, agreeable cooperation of patients in entrepreneurship processes by nurses, as well as harmonious social coexistence with the healthcare environment which in itself cannot protect.
\end{abstract}

Keywords: Ethics, entrepreneurship, health care, nursing

JEL Codes: 3 2-Digit JEL codes, 10 punto, calibri

\section{INTRODUCTION}

The nature of healthcare delivery is maintained to be reshaped by the compelling forces consisting of technological developments, the changes in healthcare economics and the increased patients involvement (Volker, 2003; Yıldırım and Kadıoglu 2007). Various ethical issues emerge concerning how to best use these resources in order to acquire the good for both individuals and society. All patients, nurses, families, physicians, other health professionals and legislators are faced with difficult preferences (Volker, 2003).

Nursing is an indispensable part of health care services (Dinç, 2009). Nurses can provide care by having knowledge and skills required by the age, being sensitive to the humanitarian and ethical aspects of care, continuously developing their professional competence and providing services appropriate to professional ethics (Arslantaş, 2015).

\section{ETHICAL SCIENCE}

The scope of ethics had improved with the history of humanity. Ethics is a broad term used to describe that branch of philosophy focused on understanding moral aspects of life. It is a term that is derived from the words of "Ethos, Ethike" in Greek and that is called "törebilim" or ahlakbilim" in Turkish. It is also defined as the scientific study and the science of morality. The theme of ethics or philosophy of ethics is human actions (Bountain, 2017; Beauchamp and Childress, 2001; Karaöz, 2000; Ulusoy and Görgülü, 2001; Volker, 2003).

Ethics includes the researches related to social, moral and social norms and philosophical reflections of practices. Ethics is the practical application of philosophy of ethics by asking the question of "what should I do in this situation". Ethical study allows nurses to make logical and lasting decisions. These decisions are based on ethical or formal moral theories. To carry out study on ethics provides nurses with a structured guideline. However, it does not tell us what we have to do. We have to choose this appropriate to ourselves (Alpar et al.2013). 
Three types of ethics are mentioned in the literature. 1) Descriptive Ethics; it is an ethical understanding in which behaviors are only examined from moral aspects and moral judgment is not made. 2) Metahetical Ethics; it is an ethical understanding that deals with the issues such as verifying behaviors, investigating the moral causes of behaviors, and giving meaning to them. 3) Normative Ethics; it is an ethical understanding that questions what is right or what needs to be done in moral issues that need to be decided. "Moral" is the Latin equivalent of ethics and means morality. Morality is the code of conduct followed by individuals and groups in a particular period of a particular society (Bountain, 2017; Ulusoy and Görgülü, 2001).

\section{ETHICS AND NURSING}

Because of the ethical questions caused by the developments in science, medicine and biotechnology, ethics are extremely important in health care (Cerit and Dinç, 2012).

For more than a century, nurses have struggled for professionalism. As a crucial constituent of professional health care services in institutions, communities and homes, nursing activities take place in thousands of instances on a daily basis. More time is spent with patients by nurses compared to any other health-care professionals since caring is a continuous process. The presence of close correlation between nurses and patients allows nurses to observe disease experiences and suffering of patients, and the nurses are required to meet ethics issues with those patients by them (Cerit and Dinç, 2012).

It has been commonly acknowledged that nurses face with exclusive nursing ethical problems resulting from their involvement in patient care (Gastmans, 2002).

Ethics is gaining an increasingly significant place in nursing. Today, there is not a consensus on the meaning of term nursing ethics in nursing literature. This term is unluckily used by numerous authors without any explanation of its definition or intended meaning (Volker, 2003). It was argued by Bishop and Scudder (2001) that "actually, nursing ethics is mainly related to expressing the moral sense of nursing and evaluating how it is accomplished instead of implementing ethical theories to nursing practice". However, it is argued by Thomasma (1994) that "nursing ethics is related to the basically improving relationship. It is required for improving; hence the ethical issues result from the task".

As a consequence of global developments and changes in health care, nurses face with new ethical issues (Görgülü and Dinç, 2007). As it is reported by the International Council of Nurses, the promotion of health, prevention of illness and the care of sick, disabled and dying people are included in nursing. To care for poor people is obvious in this definition. Caring needs more than theoretical knowledge and technical skills, and affective components involving the awareness of others' vulnerability, paying attention to caring requirements and a moral response to the requirements are included in caring (Cerit and Dinç, 2012).

Nurses refrain from permitting personal values to damage their treatment for patients in professional ethical practice. So, it is concluded that the ethical practice of nearly all nurses is put to the test on an everyday rather than an occasional basis (Woods, 1999). For instance, a specific nurse can value andor in family relationships while a specific nurse can value vandor in family relationships, however a nurse should act upon the professional ethics responsibility to sustain patient confidentiality (Bountain, 2017).

The ethical challenges that emerge in healthcare are included in recurrent ethical problems, nursing practices cannot be always supported by the institutions effectively. But, that shows that many of the nurses care professionals in spite of extensive research findings (Leutor et al., 2012).

Nurses constitute the biggest health care profession in the USA and ensure a specific type of care (nursing care) which is central to the well-being of those who require it. To improve health and to help individuals to overcome the disease are always the purposes of nursing care. While providing nursing care, nurses establish relationships with the patients and their families and are usually involved in more sustained interaction with them compared to any other member of the health care team. In addition, nurses have a crucial role in the health care team, in holding the lines of communication open and in coordinating all the professional services needed for patient care (Redman and Fry, 2000).

The fact that nurses are faced with ethical conflicts while providing care is not surprising. Nurses are individuals who have personal and professional values, they employ their skills in institutions together with the other professionals with different values. They deliver nursing care to the patients who generally have religious, cultural and moral values that are completely different from their own values (Redman and Fry, 2000).

\section{NURSE ENTREPRENEURS}

The nurse is regarded as "the owner of a business that provides nursing services of a direct care, educational, research, administrative or consultative nature. The self-employed nurse is directly liable to the patient, to whom, or on behalf of whom, nursing services are offered" by nursing entrepreneurship which is generally called as private practice, independent practice, independent contractor, and self-employed practice (ICN, 2004). 
Nowadays, an excellent population of the liberated professionals consists of nurse entrepreneurs. Nurse entrepreneurship is very beneficial in terms of financial stability, freedom, flexibility, status, increased patient and professional satisfaction (Leong et al.,, 2008). Nursing entrepreneurship is represented as a practicable and appealing approach in terms of nursing practice serving to reestablish the professional autonomy, improve nursing professionalism, engage in health system transformation. Furthermore, the nurses with self-employment opportunities are enabled to follow their personal feelings to promote the health consequences using innovative approaches, through the nursing entrepreneurship. The significant contributions that the nurse entrepreneurs made within the health care systems are increasingly realized, and it is accepted that nurse entrepreneurship is promising for the future advancement in health care.

Nurse entrepreneurs consist of the nurses with control over and responsibility for an increased proportion of indirect processes of care in their roles. Nurse entrepreneurs are required be competent and accountable to be professionally reliable. An excellent practice nurse entrepreneur is defined as a person who is capable of determining a patient's requirement and finding a way for nursing to respond to that requirement effectively, formulating and implementing a plan to fulfill that requirement. Although the basic responsibility lies with the individual nurse entrepreneur, the professions should also apparently develop these crucial attributes. An explicit scope of the practices of nurse entrepreneurs, educational and practice standards, the relevant on-going education programs, and functioning regulatory bodies such as council and accrediting body are needed between the structures (Dayhoff and Moore, 2002).

There has been an increase in inclination to entrepreneur nursing during the recent decades and under the influences of various economic and social factors. Besides, the role of entrepreneur is owned by only $0.5-1 \%$ of nurses throughout the world, based upon the census of National Nurses Association. The real number could be more or less than the amount calculated. While it is less than $1 \%$ in New Zealand, it is $0.18 \%$ and more than $18 \%$ in the US and England, respectively (Jahani et al., 2016; Wilson et al., 2012).

\section{ETHICS IN NURSING ENTREPRENEURSHIP}

One of the attributes of contemporary civilization is ethics. It is comprehensively addressed and emphasized, it might equal be taught or otherwise introduced into individual's life. The economic activity is one of the fields where ethics has become increasingly significant. The costs have continued to increase in health care, and this situation alarms those who are involved within and outside the industry. Moreover, the competition between providers has been increasingly promoted by the health care systems, so this has facilitated the improvement of entrepreneurship as well as intrapreneurship ventures. Therefore, there has been an explosion in entrepreneurs during the recent twenty years (Harris et al., 2009; Victoria and Elena, 2013).

Ethics applied to entrepreneurship could provide practical guidance for solving problems. The current understanding of the phenomenon of entrepreneurship, based on humanistic views, sees it as a wide range of ways of self-realization, and not just profit (Victoria and Elena, 2013). The ethical issues of entrepreneurship, which is crucial, involve under a seemingly clear simplicity numerous. However, serious research attention has been paid to the ethical problems only in the recent times. The health care system is confronted with uniquely complex ethical problems such as basic fairness, relationships of the personnel and patient-heath care teams, distribution dilemmas and other challenges. It is necessary to raise many points of serious concern under the concept of ethics (Staniewski et al., 2015).

It is essential for continuing education to be an inseparable part of nurse entrepreneurs' practices and career development strategy. Therefore, through the code of nursing ethics, the supplementation of legal provisions and professional regulations would be constituted, the feeling of responsibility for social consequences of professional actions would be shaped, honest activities would be promoted, and non-ethical activities would be revealed and negatively qualified (Harris et al., 2009).

\section{CONCLUSION}

Ethics is one of the features of contemporary civilization. Ethics and entrepreneurship are so closely interlinked that that combination in itself could well be looked upon as one of the fundamental criteria of decision-making. One of the areas where ethics has become increasingly important is health care. The significant contributions that the nurse entrepreneurs made within the health care systems are increasingly realized, and it is accepted that nurse entrepreneurship is promising for the future advancement in health care. In consequence, ethics will contribute to coherent, favourable cooperation of patients in entrepreneurship processes by the nurses in addition to coherent social coexistence with the healthcare environment in which it cannot protect by itself.

\section{REFERENCES}


Alpar, Ş.E., Bahçecik, N., Karabacak Ü.(2013). Çağdaş Hemşirelikte Etik [Ethics and Issues in Contemporary Nursing]. İstanbul: Istanbul Tıp Kitabevi.

Arslantaş, H. (2015). Ruh sağlığı ve psikiyatri hemşireliğinde etik konular, kodlar ve standartlar [Ethical issues, codes, and standards in mental health and psychiatric nursing]. Psikiyatri Hemşireliği Dergisi;6(1):47-56.

Beauchamp, T. L., Childress, J. F. (2001). Principles of Biomedical Ethics (5th ed.). New York: Oxford University Press.

Bishop, A., Scudder, J. (2001). Nursing Ethics: Therapeutic Caring Presence (2nd ed.). Boston: Jones and Bartlett Publishers.

Bountain, D.M. (2017).Values, Ethics, and Legal Issues. Fundamentals of Nursing Human Health. Eight Edition, Philadelphia: Wolkers Kluwer.

Cerit, B., Dinç, L. (2012). Ethical decision-making and professional behaviour among nurses: a correlational study. Nursing Ethics 20(2): 200-212.

Dayhoff, N.E., Moore, P.S. (2002). Entrepreneurial clinical nurse specialists: innovators of patient care. Clin Nurs Spec 16: 274-276.

Dinç, L. (2009). Hemşirelik hizmetlerinde etik yükümlülükler [Ethical responsibilities in nursing services]. Hacettepe Tıp Dergisi 40: 113-119.

Gastmans, C. (2002). A fundamental ethical approach to nursing: some proposals for ethics education. Nursing Ethics 9(5): $494-507$.

Görgülü, S., Dinç, L. (2007). Ethics in Turkish nursing education programs. Nursing Ethics 14(6):741-752.

Harris J.D, Sapienza H.J., Bowie N.E. (2009). Ethics and entrepreneurship. Journal of Business Venturing 24: 407-418.

International Council of Nurses. (2004). Guidelines on the Nurse Entre/Intrapreneur providing nursing service. Author. Geneva, Switzerland: ICN.

Jahani, S., Abedi, H., Elahi, Fallahi-Khoshknab (2016). Iranian entrepreneur nurses' perceived barriers to entrepreneurship: A qualitative study. Iran J Nurs Midwifery Res 21(1): 45-53.

Karaöz, S. (2000). Cerrahi hemşireliği ve etik [Ethics in perioperative nursing]. C.Ü. Hemşirelik Yüksekokulu Dergisi 4 (1):1-15.

Kulwicki, E. (2011). Social and ethical aspects of entrepreneurship. The Małopolska School of Economıcs In Tarnów Research Papers Collection 19(1): 55-63.

Leuter, C., Petrucci, C., Mattei, A., Tabassi, G., Lancia, L. (2012). Ethical difficulties in nursing, educational needs and attitudes about using ethics resources. Nursing Ethics 20(3): 348-358.

Leung, B., Wee Shan, A.K., Yuen-Ping, H. (2008). Is an enterprise framework necessary for an entrepreneurial university? A comparison of technology start-ups in Singapore and Sweden. Science and Public Policy, 35(9):647-656.

Redman B.K., Fry, S.T. (2000). Nurses' ethical conflicts: what is really known about them? Nursing Ethics 7 (4): 360-366.

Staniewski, M.W., Slomski, W., Awruk, K. (2015). Ethical aspects of entrepreneurship. Filosofija. Sociologija 26(1):37-45.

Thomasma, D. C. (1994). Toward a new medical ethics: Implications for ethics in nursing. In P. Benner (Ed.), Interpretive phenomenology: Embodiment, caring, and ethics in health and illness. Thousand Oaks, CA: Sage.

Ulusoy, M.F., Görgülü, R.S. (1991).Hemşirelik Esasları Temel Kuram, Kavram, Illke ve Yöntemler [Fundamentals of Nursing: Basic Theories, Concepts, Principles and Methods), Ankara:72 TDFO Ltd.Şti.

Victoria, D., Elena,L. (2013). Moral and ethical conceptions of entrepreneurs: cross-cultural aspects. Procedia - Social and Behavioral Sciences 86: $318-322$.

Volker, D.L. (2003). Is there a unique nursing ethic?. Nursing Science Quarterly 16(3): 207-211

Wilson A, Whitaker N, Whitford D. (2012). Rising to the challenge of health care reform with entrepreneurial and intrapreneurial nursing initiatives. Online J Issues Nurs 17: 5.

Woods, M. (1999). A nursing ethic: the moral voice of experienced nurses. Nursing Ethics 6 (5):423-433.

Yıldırım, G., Kadıŏlu S. (2007). Etik ve tıp etiği temel kavramları [Basic concepts of ethics and medical ethics]. C.Ü. Tıp Fakültesi Dergisi 29 (2): 7-12. 